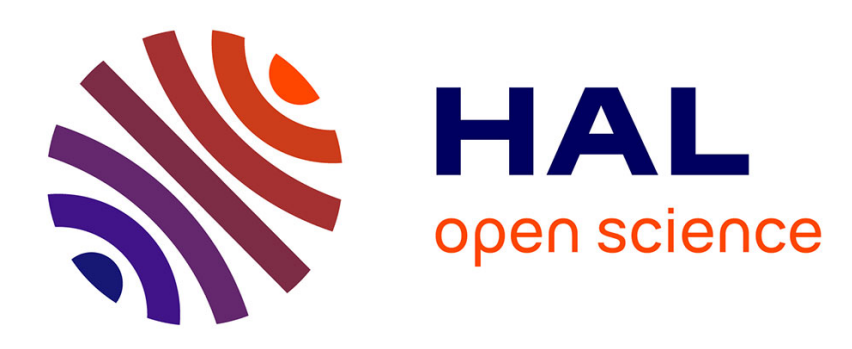

\title{
Does Price Influence Assessment of Fundamental Value? Experimental Evidence
}

\author{
Sylvain Marsat, B Williams
}

\section{To cite this version:}

Sylvain Marsat, B Williams. Does Price Influence Assessment of Fundamental Value? Experimental Evidence. Journal of Behavioral Finance, 2013, 14, pp.268 - 275. 10.1080/15427560.2013.848866 . hal-02156599

\section{HAL Id: hal-02156599 \\ https://hal.science/hal-02156599}

Submitted on 14 Jun 2019

HAL is a multi-disciplinary open access archive for the deposit and dissemination of scientific research documents, whether they are published or not. The documents may come from teaching and research institutions in France or abroad, or from public or private research centers.
L'archive ouverte pluridisciplinaire HAL, est destinée au dépôt et à la diffusion de documents scientifiques de niveau recherche, publiés ou non, émanant des établissements d'enseignement et de recherche français ou étrangers, des laboratoires publics ou privés. 


\title{
Does Price Influence Assessment of Fundamental Value?
}

\author{
Experimental Evidence
}

\author{
Version accepted for publication in: \\ Marsat, S., Williams, B., 2013. Does Price Influence Assessment of Fundamental Value? \\ Experimental Evidence. Journal of Behavioral Finance 14, 268-275
}

\author{
Sylvain Marsat \\ Associate professor of finance \\ Clermont Université \\ Université d'Auvergne, CRCGM Research Center \\ Faculty of Economics and Management / IAE \\ 41, Bd F.-Mitterrand BP 54 \\ F-63002 Clermont-Fd Cedex - France \\ Tel: +3347317 7588 \\ E-Mail: sylvain.marsat@u-clermont1.fr
}

Benjamin Williams

Associate professor of finance

Clermont Université

Université d'Auvergne, CRCGM Research Center Faculty of Economics and Management / IAE 41, Bd F.-Mitterrand BP 54

F-63002 Clermont-Fd Cedex - France Tel: +3347317 7621

E-Mail: benjamin.williams@u-clermont1.fr

Corresponding author: Benjamin Williams

\begin{abstract}
Assessing the fundamental value of a firm is a difficult task. Theoretically, the market price is exogenous and should not be used in the estimation. We performed a simple experiment to pinpoint whether price is used in fundamental value calculation. Subjects were given similar information on a firm. In the first/control situation, no price was submitted. In the second situation, the actual price was submitted to them. In the third one, a manipulated, overvalued price was provided. We find that the price provided, whatever it is, proves to have a clear impact on the subjects' estimations. This is consistent with the anchoring-andadjustment hypothesis of fundamental assessment and has implications for a better understanding of financial bubbles.
\end{abstract}

Keywords: fundamental value, price, experiment, anchoring

JEL classification: G12, G14 


\section{INTRODUCTION}

Fundamental value is a key concept in financial theory. It is the value an asset is worth according to its intrinsic characteristics: expected cash flows, risk, maturity, etc. Unlike price, which is common knowledge resulting from transactions, value has to be assessed by individuals. This fundamental value is useful for anyone who expects to buy or sell an asset. As the saying goes, "buy cheap; sell dear" is the safest way to make a profit. The mere comparison between price and estimated value enables the investor to ascertain whether an asset is cheap or dear.

On the stock market, two different approaches can be used to assess this fundamental value. The first one relies on discounting expected cash flows provided by the asset (Fisher [1930], Williams [1938] and Gordon and Shapiro [1956]). This method is the most popular among practitioners of finance (Viebig et al. [2008]). The second approach considers value as the actual net book value plus a goodwill that assesses intangible assets, since they are a potential for profit (Graham and Dodd [1951] and Ohlson [1995]). Thus, whatever the valuation method used, price should not be relevant in estimating fundamental value.

Actually, the relationship between value and price is more complicated than one would think. Grossman and Stiglitz [1980] demonstrate that it can be rational to introduce the price in the dataset insofar as it conveys information on fundamentals. The informational content provided by the price results from estimations and expectations of market operators. From this standpoint, price is a voting mechanism (Graham and Dodd [1951]). Northcraft and Neale [1987] investigate a different approach. In an experiment, they study the role of price as an anchor for value assessment. They prove that, in the real estate sector, both experts and amateurs are highly influenced by the price provided, even if it is manipulated. The authors conclude that subjects are prone to anchor to price and then adjust. 
This paper investigates the influence of stock prices in assessing the fundamental value of firms through a simple experiment allowing us to examine the way individuals process a price in their decisions. We assume that three behaviors can be observed: investors never use the price; they use it when they assume it is relevant; they always use it, whether it is relevant or not.

In order to ensure control and collection of data, a questionnaire was used. We provided subjects with financial and general data on an actual firm, asking them to assess its fundamental value. Three different situations enabled us to distinguish the role of price in the estimation of fundamental value. In control situation S1, subjects did not have access to the market price. The real price was provided to subjects of situation S2. In situation S3, an "unfair", overvalued and manipulated price was submitted. The results are consistent with the anchoring-and-adjustment hypothesis as defined by Northcraft and Neale [1987], since the price, whether real or not, proves to have a significant influence on the assessment of fundamental value.

This paper is organized in the following way. First, the literature about fundamental value and the hypotheses is discussed (1). Then, we develop the methodology and details of the questionnaire used (2), before presenting the main results of the experiment (3).

\section{FUNDAMENTAL VALUE AND PRICE}

\section{What is fundamental value?}

Fundamental value is a widely used concept. However, a precise definition is actually very hard to find. According to Graham and Dodd [1951], fundamental or intrinsic value could be defined as the value a stock is worth thanks to the analysis of data about its fundamentals (i.e. all information about past, present and expected activities and assets). "A 
general definition of intrinsic value would be 'that value which is justified by the facts - e.g., assets, earnings, dividends, definite prospects"” (Graham and Dodd [1951, p. 16]).

In her review of valuation techniques, Rutterford [2004, p. 134] defines "intrinsic or fair value [as] the true worth of a share, regardless of its market price." Therefore, fundamental/intrinsic/fair value should theoretically not be affected by market price dynamics induced by short-term speculation. If the market is not purely efficient, fundamental value can differ significantly from price. The Internet stock bubble is often cited as a striking example of mispricing, showing the gap between fundamental value and market price (Shiller [2000]). When this gap is relatively small, the price can be considered "fair" (Rutterford [2004, p. 134]). On the other hand, when the gap is large, price is perceived as "unfair", i.e. not right or appropriate according to fundamentals. In this situation, either the price seems too high and the share is dear/overpriced or the price seems too low and the share is cheap/underpriced. The detection of underpriced stocks is the cornerstone of a value investment style (Graham and Dodd (1951) and Buffet [1998]).

Formally, and following Grossman and Stiglitz [1980] and Lee et al. [1999], if we call $P_{i}$ the price of firm $i ; V_{i}$ the fundamental value of firm $i$ and $\varepsilon_{\mathrm{i}}$, the gap between price and fundamental value:

$$
\operatorname{Ln}\left(P_{i}\right)=\operatorname{Ln}\left(V_{i}\right)+\varepsilon_{i}
$$

if $\varepsilon_{i} \sim 0: P_{i}=P_{f, i}$, i.e. when $\varepsilon_{i}$ is small, the price is fair (henceforth $P_{f, i}$ ); otherwise: $P_{i}=P_{u, i}$, i.e. when $\varepsilon_{i}$ is large, the price is unfair (henceforth $P_{u, i}$ ).

\section{Fundamental value estimations}

In order to assess fundamental value, two main techniques are proposed. One can estimate the value of an asset either by assessing its future income or using its patrimonial value plus goodwill (Graham and Dodd [1951]). 


\section{The present value model}

In 1930, Irving Fisher wrote a major contribution to the foundations of finance in his Theory of Interest. He clearly defines the way value can be calculated: "Savings bring us to the nature of capital. Capital, in the sense of capital value, is simply future income discounted or, in other words, capitalized. The value of any property, or rights to wealth, is its value as a source of income and is found by discounting that expected income" (Fisher [1930], p.12-13).

According to this assumption, the value of assets is found by discounting expected incomes. Applying this to stock markets means that the value is the present value of future dividends, as presented in Williams' famous book [1938] through the Dividend Discounted Model (DDM). Under the transversality hypothesis - equation (3) -, the fundamental value of firm $i$ is the sum of discounted expected dividends:

$$
\begin{gathered}
V_{i}=\sum_{t=1}^{\infty} \mathrm{E}\left[D_{i, t} \mid \Phi_{i}\right](1+r)^{-t} \\
\operatorname{Lim}_{t \rightarrow+\infty} P_{i, t}(1+r)^{-t}=0
\end{gathered}
$$

with $V_{i}$, the value of firm $i$; $D_{i, t}$, the dividend paid by the firm $i$ at time $t$; $r$, the discount rate and $P_{i, t}$, the price of stock $i$ at time $t$; $\Phi_{i}$, the information set concerning firm $i$.

Extensions of this model are widespread. Gordon and Shapiro [1956], Molodovsky [1960], Gordon [1962], Bates [1962], Holt [1962], Molodovsky, May and Chottiner [1965] or Fuller and Hsia [1984] postulate different rates and periods of dividend growth. We do not intend to provide a full review of these numerous models here since they all rely on the same assumption - discounting expected dividends. According to Rutterford [2004] and Buckley [2003, p. 636], these models are generally viewed as the "gold standard of valuation".

\section{Graham and Dodd's approach}

In their seminal book entitled Security Analysis, initially published in 1937, Graham and Dodd combine asset valuation and discounting methods. This conception includes 
expected dividends and earnings as well as present assets. Investors collect a wide variety of information (balance sheets, operating income, expected cash flows, financial structure, management and strategy, business environment), enabling them to assess the firm.

Formally, the fundamental value of a firm can be viewed as the sum of its liquidation value and a "goodwill". The liquidation value is equal to the value the assets could be sold at, less the debts the firm has to reimburse. Therefore, the net worth value (also sometimes called "scrap value") is equal to the book value of assets minus debts. Accounting value has sometimes, of course, to be reevaluated. Buildings and properties should, for instance, be sold at the market price, and could be worth far more than the gross price paid years ago. Some immaterial assets (e.g. quality of clients, know-how, strategy...) may be assessed in the "goodwill". Formally, this can be defined as the present value of abnormal earnings (Ohlson [1995] and Lee et al. [1999]):

$$
V_{i}=B_{i}+\sum_{t=1}^{\infty} \mathrm{E}\left[N I_{i, t}-r_{e} . B_{i, t-1} \mid \Phi_{i}\right]\left(1+r_{e}\right)^{-t}
$$

with $V_{i}$, the value of firm $i ; B_{i, t}$, the book value at time $t ; N I_{i, t}$, net income for period $t ; r_{e}$, the cost of equity capital and $\Phi_{i}$, the information concerning firm $i$.

\section{Hypotheses regarding fundamental value and price}

In order to assess fundamental value, price may have (i) no impact, (ii) an influence when price is fair and (iii) an influence, whatever the price is. These hypotheses are discussed in this section.

\section{H1: Rational expectations}

According to the main theoretical approaches in estimating the fundamental value of a stock, diverse data is processed. However, whatever the method, price is not relevant for the evaluation (Rutterford [2004]). Therefore, the price is exogenous and should not influence 
this assessment, i.e. operators assess the fundamental value of assets without taking the price into account. We call $V_{i}$ the fundamental value and $\Phi_{i}$ the information set concerning firm $i$. This information set does not include the price of stock $i$, i.e. $P_{i} \not \subset \Phi_{i}$. The price $P_{i}$ can be a fair price, $P_{f, i}$, or an unfair price, $P_{u, i}$. This is our first hypothesis:

H1: Only fundamental data is processed in assessing the fundamental value of firm $i: V_{i}\left(\Phi_{i}\right)=V_{i}\left(\Phi_{i}, P_{f, i}\right)=V_{i}\left(\Phi_{i}, P_{u, i}\right)$

These agents have stricto sensu rational expectations (Muth [1961]) and base their assessment on the real model of the economy, i.e. discounting cash flows (e.g., Fisher [1930] and Williams [1938]) and/or using other data that they consider relevant in the assessment (Graham and Dodd, [1951]).

\section{H2: Economically rational expectations}

However, market price should give an estimation of fundamental value, since the price reflects fundamentals Fama [1965]. Grossman and Stiglitz [1980] show that in an efficient market, it can be better for actors with economically rational expectations (Jensen [1978]) to rely on market price since they avoid processing information and transaction costs. Actually, "when there is no noise, prices convey all information, and there is no incentive to purchase information" (Grossman and Stiglitz [1980], p. 395). In this case, agents use $\Phi_{i}$ and fair price $P_{f, i}$, which is close to $V_{i}$. Yet, after a while, the proportion of uninformed agents, ignoring fundamental information, increases. The price becomes unfair since it moves away from fundamental value. At this stage, the cycle will reverse because "if everyone is uninformed, it clearly pays some individual to become informed" (Grossman and Stiglitz [1980], p. 395). Therefore, fair price is interesting data for operators to assess fundamental value when the gap between price and fundamental value is small. Agents do not take into account unfair prices that they consider less credible (Northcraft and Neale [1987]). 
H2: Fundamental data and a fair market price are used in assessing the fundamental value of firm $i: V_{i}\left(\Phi_{i}\right)=V_{i}\left(\Phi_{i}, P_{u, i}\right) \neq V_{i}\left(\Phi_{i}, P_{f, i}\right)$.

\section{H3: Anchoring-and-adjustment}

The price, whatever it may be, proves to be considered an anchor for an agent in the event of uncertainty. Tversky and Kahneman [1974] asked subjects to evaluate the number of African countries that are members of the UN. Their answers were affected by a number, even when it was presented as randomly chosen between 0 and 100 . However, an anchor is not necessarily a random number; it can also consist in a market price (e.g., Northcraft and Neale [1987], Vitting Andersen [2010]). Referring to Slovic and Lichtenstein [1971], Northcraft and

Neale [1987, p. 85] summarize the anchoring-and-adjustment phenomenon: "The psychological literature on the 'anchoring-and-adjustment' heuristic suggests that (a) an arbitrarily chosen reference point (anchor) will significantly influence value estimates, and (b) value estimates will be insufficiently adjusted away from the reference point toward the true value of the object of estimation". When asked to assess a property, subjects were significantly influenced by the manipulated average price of the houses around it. Similarly, an unfair price might also be used in the evaluation process since agents are not able to distinguish fair and unfair prices. For the remainder of this paper, anchoring-and-adjustment refers to the definition given by Northcraft and Neale [1987].

H3: Fundamental data and both fair and unfair prices are used in assessing the fundamental value of firm $i: V_{i}\left(\Phi_{i}\right) \neq V_{i}\left(\Phi_{i}, P_{f, i}\right) \neq V_{i}\left(\Phi_{i}, P_{u, i}\right)$.

An overvalued, unfair price leads to higher fundamental value estimation and an undervalued price leads to lower fundamental value since agents adjust $V_{i}$ to $P_{u, i}$ :

Corollary 1: if $P_{u, i}>P_{f, i}$ then: $V_{i}\left(\Phi_{i}, P_{u, i}\right)>V_{i}\left(\Phi_{i}, P_{f, i}\right)$, otherwise $V_{i}\left(\Phi_{i}, P_{u, i}\right)<V_{i}\left(\Phi_{i}, P_{f, i}\right)$ 


\section{METHODOLOGY}

In order to test these three hypotheses, different information sets were needed. Therefore it was not possible to conduct our experiment with market data, whereas an experimental design enabled us to investigate the behaviors of individuals towards the price. We chose a between-subjects design in order to isolate the influence of price in the valuation experiment. It also allowed us to avoid an informational cascade in the experiment, by giving all the subjects three consecutive information sets (i.e., with no price, actual price and manipulated price).

\section{Experimental situation}

General and financial data from a real and fair-valued French firm was submitted to the test subjects. They were asked to assess the fundamental value of this company. In order to pinpoint the role of price in the determination of fundamental value, subjects were divided into three groups, corresponding to three different situations:

S1: Subjects who did not have access to the stock price in their evaluation

S2: Subjects who did have access to the actual stock price in their valuation

S3: Subjects to whom a manipulated, overvalued stock price was submitted

These situations allow us to discriminate between the three hypotheses. The actual stock price was used in situation S2 as the fair price $P_{f, i}$. In order to obtain an unfair price $P_{f, i}$, we significantly inflated the stock price. This manipulated price was given to subjects in situation S3. Besides the stock price, the information set $\Phi_{i}$ given to all subjects was exactly the same (see Appendix). Based on the information they received, subjects had to give an estimation of fundamental value.

The firm was chosen among those listed on the French small capitalization market in order to avoid selecting a well-known firm. To find a fair-valued firm, we selected it through 
a screening based on Price Earning (P/E), Price to Book (P/B) and Return on Equity (RoE), relative to its CAC Small 90 benchmark. The criterion applied was:

$$
\operatorname{Min}\left(\left|\mathrm{P} / \mathrm{E}_{i}-\overline{\mathrm{P} / \mathrm{E}}\right|+\left|\mathrm{P} / \mathrm{B}_{i}-\overline{\mathrm{P} / \mathrm{B}}\right|+\left|\mathrm{RoE}_{i}-\overline{\mathrm{RoE}}\right|\right)
$$

with $\mathrm{P} / \mathrm{E}_{i}, \mathrm{P} / \mathrm{B}_{i}$ and $\mathrm{RoE}_{i}$, the ratios concerning firm $i ; \overline{\mathrm{P} / \mathrm{E}}, \overline{\mathrm{P} / \mathrm{B}}, \overline{\mathrm{RoE}}$, the mean of these ratios among the CAC Small 90 benchmark.

The firm selected was Tonnellerie François Frères $S A^{1}$, "a company based in France that manufactures and distributes oak barrels used to store and transport [high quality wines]" (from latest annual audited report, Reuters). This industry is traditional, somewhat "brick and mortar", and should be easier to evaluate than new technology firms.

The information set $\Phi_{i}$ included a general presentation of the company and its products, a geographical breakdown of sales, a brief SWOT analysis, an overview of economic conditions, balance sheet statements from 2003 to 2006, income statements from 2003 to 2006, as well as forecasts from 2007 to 2009, ratios (EPS, CPS and DPS) and RoE of comparable firms. The content of this company profile was largely inspired from an actual analysis provided by Berenberg, a German private bank.

The fair price $P_{f, i}$ was the actual closing price of the stock on March $3^{\text {rd }} 2008$ (EUR 36.76). The manipulated price $P_{u, i}$ was overvalued. The unfair price $P_{u, i}$ was calculated as a 50 percent increase over the average price history of the firm during the previous year. From March $5^{\text {th }} 2007$ to March $3^{\text {rd }} 2008$ the average price was EUR 40.07 and therefore $P_{u, i}$ was set at EUR 60.11. This is far above the historical highest price of EUR 47.79.

\section{Subjects and procedure}

Subjects were chosen among students enrolled in a Master's degree in finance or accounting. They all attended advanced courses on firm valuation. This experimental design allowed us to control for education. Among the 188 subjects, two questionnaires were 
excluded because the subject recognized the firm and one because the subject had guessed the hypotheses tested. Then, five questionnaires were set aside because the fundamental value was considered aberrant, i.e. more than three times the interquartile range above the third and below the first quartile.

The questionnaire was administered in March 2008. Subjects were informed that they were selected for an experiment concerning stock valuation. The experiment was not presented as an examination. They were given the questionnaire, including the information set and calculators. They were not allowed to talk to each other. In order to avoid cheating, each situation was presented as independent, with different corporate names ${ }^{2}$ and different presentations (colors and fonts) for students sitting side by side.

In order to motivate subjects in this experiment, they were told that the ten best estimations $^{3}$ would be rewarded by a EUR 20 coupon towards the purchase of music and books. This incentive was considered interesting and motivated them to do their best. After asking them if they had any questions, they were allowed 30 minutes to fill in the questionnaire. The time allowed was considered sufficient by the subjects and the experiment was run over a 24-hour period.

\section{RESULTS AND DISCUSSION}

The following section presents the main results of the experiment we conducted with 188 students. Among the 180 questionnaires actually used, $43.3 \%$ of the subjects were women. Most of the subjects were quite familiar with financial markets since $15 \%$ had been members of investment clubs, $61.7 \%$ had already played an investment simulation game and $27.8 \%$ had already bought stocks.

The influence of price on the assessment process is measured through the distribution of fundamental value estimations. The diagram below represents these distributions, provided 
by the subjects in the three situations. The three vertical lines correspond to net asset value, actual price and manipulated price.

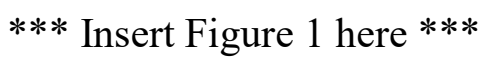

The introduction of a price modifies the estimations provided by the test subjects. In situation S1, where no price was given, the median of the estimates is 21.5 . In situation S2, with the true price (36.76), the median moves to 26.0. In situation S3, with the manipulated price (60.11), the median rises to 39.1. The median increase is, to a certain extent, proportional to the price increase. Indeed, the median variation $(+50.4 \%)$ is close to the price manipulation $(+63.5 \%)$.

The bulk of these estimations are close to net asset value (20.06). In situation S1, 9 of the 59 subjects considered that fundamental value equals liquidation value. If we consider estimates between ${ }^{4} 19$ and 21 , the proportion is $31 \%$ for situation $\mathrm{S} 1,27 \%$ and $11 \%$ for situations S2 and S3 respectively. The table below presents descriptive statistics for fundamental value estimates. They are given for each situation and for the overall sample.

\section{*** Insert Table 1 here ***}

To compare the dispersions among the three situations, we compute a normalized interquartile range (IQR) defined as $\left(\mathrm{Q}_{3}-\mathrm{Q}_{1}\right) /$ Median. This IQR-to-median ratio is respectively equal to $0.30,0.50$ and 0.78 in situations $\mathrm{S} 1, \mathrm{~S} 2$ and $\mathrm{S} 3$. When a true price is given to the subjects, the relative dispersion is 1.67 times the one in situation $\mathrm{S} 1$. When a manipulated price is introduced, this ratio increases to 2.63 times. The addition of prices in the data set created noise, especially in situation S3, when a manipulated price is given since adding a price leads to a larger dispersion of estimations.

If these distributions seem to be different at first glance, there is no proof they are statistically robust. A Kruskal-Wallis test rejects significantly $(\mathrm{p}<0.000)$ the hypothesis of 
distribution homogeneity between the three situations. These results refute hypotheses $\mathrm{H} 1$ and $\mathrm{H} 2$, since they imply the equality of at least two distributions. The Kruskal-Wallis test is consistent with the anchoring-and-adjustment hypothesis (H3) since the three different information sets lead to three heterogeneous distributions.

\section{*** Insert Table 2 here ***}

In this experiment, price proves to have an impact on the firm's fundamental value and subjects apparently do not distinguish between actual price and manipulated price. Anchoring pinpoints an endogenous situation between price and value and, in particular, a feedback effect of price on fundamental value:

$$
V_{i}=g\left(P_{i}, \Phi_{i}\right)
$$

The estimations given in situations S2 and S3 are influenced by the anchor, since even a manipulated, overvalued price is integrated in the assessment process. According to corollary 1 , an overvalued, unfair price leads to a higher median of estimated fundamental value. Therefore, agents seem to adjust $V_{i}$ to $P_{u, i}$. More generally, if we consider function $g$ as a linear weighted average, we obtain the equation (6):

$$
V_{i}=\alpha P_{i}+(1-\alpha) f\left(\Phi_{i}\right)
$$

with $\alpha$, the anchoring parameter, $0<\alpha<1$ under hypothesis $\mathrm{H} 3$.

Since numerous answers given by subjects cited the net asset value as the best estimate of fundamental value, we postulate a very simple model where the function $f\left(\Phi_{i}\right)$ is reduced to the mere net asset value for simplicity. Using equation (7) and measuring $V_{i}$ as the median of estimates in each situation, we find an $\alpha$ equal to 0.36 in situation S2 and 0.48 in situation S3. Paradoxically, the manipulated price, while clearly higher than the actual price, has an even greater influence on assessment of fundamental value. This does mean that the noise embedded in the manipulated price increases the influence of the anchor. 
While subjects used price in their estimation, they also attached less importance to other exogenous information. When subjects were given a manipulated price, they asserted using less data from the balance sheet in assessing fundamental value (Mann-Whitney U-Test at a 5 percent signification). The results show that most of the subjects gave less weight to accounting information and anchored their estimation on the unfair market price.

\section{CONCLUSION}

The valuation experiment we performed offers evidence that subjects tend to fall into the anchoring trap. The main contribution of this paper is that fundamental value estimations are influenced by market price whatever it is (actual price or manipulated price). This finding is consistent with the anchoring-and-adjustment hypothesis of fundamental assessment (Northcraft and Neale [1987]).

To a certain extent, price is the mere result of a consensus. "[...] for some judgments (such as beauty or value), there may be no absolute truth" (Northcraft and Neale [1987], p. 98). In the absence of an objective value, price is a convenient anchor that influences personal beliefs. An interview with a portfolio manager illustrates this phenomenon in the case of crude oil (Marsat [2006, p. 166]): “[...] Today, when we make a survey... I attended a session in which we were asked [...] "do you believe that today there is a speculative premium [overvaluation of crude oil]?" And no one raised his hand. Whereas six months or one year ago, everyone said that there was a $\$ 5$ or $\$ 10$ speculative premium due to the geopolitical situation, hedge funds or other things. Today, everyone accepts this data objectively."

For these operators, the price, which was once seen as overvalued and unfair, is taken for granted and fair a few months afterwards. They changed their perceptions of the fundamentals rather than calling the evolution of price into question. This anchor on market price is also consistent with behaviors observed during the Internet stock bubble, when 
operators disregarded fundamental indicators like P/E (Shiller [2000]). They preferred relying on models including ad hoc growth rates that indeed rationalized stock prices.

The influence of market price in the perception of fundamental value might have a stimulating explanatory power on some anomalies documented in the theory of finance. The anchor-and-adjustment hypothesis is consistent with overreaction and high volatility since a large increase (or decrease) in price is viewed as a positive (or negative) signal for the fundamental value. This also could explain financial bubbles and their persistence. Indeed, the higher the stock price soars, the more investors are inclined to increase their estimations of its value. At the same time, as the gap between price and value narrows, operators are not even aware they are helping create a bubble.

\section{ACKNOWLEDGMENTS}

We are grateful to Patrick Roger and Richard E. Ottoo for their helpful comments. We thank François Aubert, Yves Mard, Jean-Pierre Védrine and the participants in the CRCGM Workshop, AFFI 2009 and EFMA 2009 international conferences. We also thank Klaus Röder and the participants in the Center for Finance Workshop at Universität Regensburg. The ideas, methodology and findings expressed in this paper are the sole responsibility of the authors. 


\section{NOTES}

1. Euronext Code: FR0000071904, Reuters Code: TEFE.PA. This company belongs to the CAC Small 90 benchmark.

2. Tonnellerie François Frères SA was called Société Martin Frères SA (without price), Tonnellerie Poillanges SA (with true price) and Compagnie du Clos de Melin SA (with manipulated price).

3. Since the information set was not the same for the three situations, we were not able to determinate the ten best fundamental value estimations. Instead there was a special question about the variation of the stock price over a five year period and the ten best estimations of this variation were rewarded.

4. Approximately: net asset value \pm EUR 1 . 


\section{REFERENCES}

Bates, G. “Comprehensive Stock Value Tables.” Harvard Business Review, 40(1), (1962), pp. $53-67$.

Buckley, A. "Why is Fundamental Value so Fundamental to Directors?" European Management Journal, (21)5, 2003, pp. 635-646.

Buffet, W. The Essays of Warren Buffett: Lessons for Corporate America, Cunningham Group, 1998.

Fisher, I. The Theory of Interest as Determined by Impatience to Spend Income and Opportunity to Invest it, New York, NY: The Macmillan Company, 1930.

Fama E. "The Behavior of Stock Market Prices.” Journal of Business, 38(1), (1965), pp. 34105.

Fuller, R. and J. Hsia. "A Simplified Model for Estimating Stock Prices of Growth Firms.” Financial Analyst Journal, 40(5), (1984), pp. 49-56.

Gordon, M. and E. Shapiro. "Capital Equipment Analysis: The Required Rate of Profit", Management Science, 3(1) , (1956), pp. 102-112.

Gordon, M. The Investment Financing and Valuation of the Corporation. Homewood, IL: Irwin, 1962.

Graham, B. and D. Dodd. Security Analysis, New York, NY and London: McGraw-Hill Book Company, Inc., 1951.

Grossman, S. and J. Stiglitz. "On the Impossibility of Informationally Efficient Markets." American Economic Review, 70(3), (1980), pp. 393-408.

Holt, C. "The Influence of Growth Duration on Share Prices." Journal of Finance, 17(3), (1962), pp. 465-475.

Jensen, M. "Some Anomalous Evidence Regarding Market Efficiency.” Journal of Financial Economics, 6(2/3), (1978), pp. 95-101. 
Lee, C., J. Myers and B. Swaminathan "What Is the Intrinsic Value of the Dow?" Journal of Finance, 54(5), (1999), pp. 1693-1741.

Marsat, S. Approaches of the Genesis of Herding Behaviors on the Stock Market, Clermont University: Doctoral dissertation, 2006.

Molodovsky, N. “Stock Values and Stock Prices.” Financial Analysts Journal, 16(3), (1960), pp. 9-12 (Part I) and pp.53-64 (Part II).

Molodovsky, N., C. May and S. Chottiner. "Common Stock Valuation: Principles, Tables and Application.” Financial Analyst Journal, 21(2), (1965), pp. 104-123.

Muth, F. "Rational "Expectations and the Theory of Price Movements." Econometrica, 29(3), (1961), pp. 315-335.

Northcraft, G. and M. Neale. "Experts, Amateurs, and Real Estate: An Anchoring and Adjustment Perspective on Property Pricing Decisions." Organizational Behavior and Human Decision Processes, 39(1), (1987), 84-99.

Ohlson, J. "Earnings, Book Value and Dividends in Equity Valuation." Contemporary Accounting Research, 11(2), (1995), pp. 661-687.

Rutterford, J. "From dividend yield to discounted cash flow: a history of UK and US equity valuation techniques." Accounting, Business and Financial History, 14(2), (2004), pp. $115-149$.

Shiller, R. Irrational Exuberance, Princeton, NJ: Princeton University Press, 2000.

Slovic, P. and S. Lichtenstein. "Comparison of Bayesian and Regression Approaches to the Study of Information Processing in Judgment." Organizational Behavior and Human performance, 6(6), (1971), pp. 649-744.

Tversky, A. and D. Kahneman. "Judgment Under Uncertainty: Heuristics and Biases." Science, 185(4157), (1974), pp. 1124-1131. 
Viebig, J., T. Poddig and A. Varmaz (Ed.). Equity valuation: Models from Leading Investment Banks, Chichester: Wiley, 2008.

Vitting Andersen, J. "Detecting Anchoring in financial markets." Journal of Behavioral Finance, 11(2), (2010), pp. 129-133.

Williams J. The Theory of Investment Value. Cambridge, MA: Harvard University Press, 1938. 
TABLES AND FIGURES 
Figure 1- Distribution of fundamental value estimations
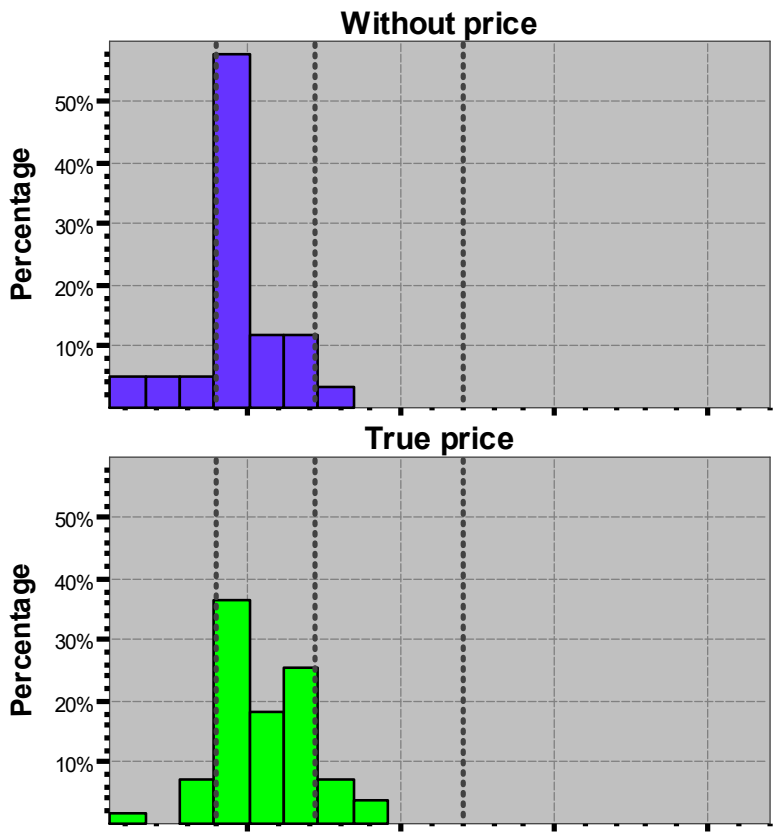

Manipulated price

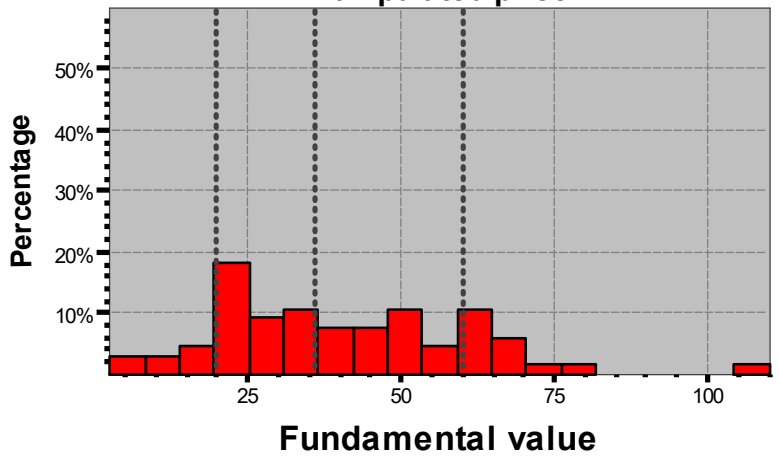


Table 1- Descriptive statistics of fundamental value

\begin{tabular}{lcccc}
\hline & $\begin{array}{c}\text { Without } \\
\text { price }\end{array}$ & $\begin{array}{c}\text { True } \\
\text { price }\end{array}$ & $\begin{array}{c}\text { Manipulated } \\
\text { price }\end{array}$ & Total \\
\hline Mean & 22.6 & 27.1 & 40.0 & 30.4 \\
Standard deviation & 7.4 & 7.8 & 20.3 & 15.6 \\
First quartile & 20.0 & 20.1 & 23.4 & 20.1 \\
Median & 21.5 & 26.0 & 39.1 & 26.0 \\
Third quartile & 26.4 & 33.0 & 54.0 & 35.8 \\
Observations & 59 & 55 & 66 & 180 \\
\hline
\end{tabular}


Table 2- Results of the Kruskal-Wallis test

\begin{tabular}{lccc}
\hline Situation & N & Median & Avg. Rank \\
\hline Without Price & 59 & 21.5 & 64.1 \\
Actual Price & 55 & 26.0 & 85.7 \\
Manipulated Price & 66 & 39.1 & 118.1 \\
Total & 180 & 26.0 & 90.5 \\
\cline { 1 - 2 } & & \\
\cline { 1 - 2 } Chi-square & 34.16 & \\
DF & 2 & \\
Prob. & 0.000 \\
\hline
\end{tabular}




\section{APPENDIX}

(See following pages)

This financial note relates to situation S2, where subjects were given the true price (EUR 36.76) and the name of Tonnellerie François Frères SA was changed to Tonnellerie Poillanges $S A$. Other financial notes are available on request. 


\section{Company Profile}

Tonnellerie Poillanges $S A$ is a company based in France that manufactures and distributes oak barrels used to store and transport high quality wines. This family firm was founded in 1910. To make barrels, the Company uses wood from forests in the French regions of Tronçais, Allier, Nevers and Vosges, as well as from Hungary. The logs are delivered to the Company's site in the village of Saint-Romain, where they are sorted, inspected, split and matured for 24 or 36 months before being sent to twelve different production sites.

Tonnellerie Poillanges SA offers four brands of barrels: "Exclusifs", "Privilèges", "Classiques" and "Horizons". The core market is "ultra premium" quality wines. These barrels are produced in different sizes, from 225-liter barrels ("Bordeaux Transport") to 600-liter barrels ("Demi Mud"). The Company has operations worldwide, mainly in the United States, France and Oceania.

Tonnellerie Poillanges SA is quoted on the Paris Stock Exchange. On March, $3^{\text {rd }} 2008$ the quotation was EUR 36.76.

Sales: geographical breakdown

\begin{tabular}{lrrrr}
\hline (in $€$ million) & $\mathbf{2 ~ 0 0 6}$ & & $\mathbf{2 ~ 0 0 5}$ & \\
\hline France & 15,061 & $16.5 \%$ & 14,661 & $19.0 \%$ \\
United States & 35,517 & $39.0 \%$ & 29,636 & $38.5 \%$ \\
Other & 40,474 & $44.5 \%$ & 32,742 & $42.5 \%$ \\
\hline TOTAL & 91,052 & $100.0 \%$ & 77,039 & $100.0 \%$ \\
\hline
\end{tabular}

\section{Strategic Analysis}

The following table summarizes opportunities and threats to Tonnellerie Poillanges SA.

\begin{tabular}{|c|c|}
\hline OPPORTUNITIES & THREATS \\
\hline $\begin{array}{l}\text { - } \quad \text { Low debt ratio (debt to shareholders' } \\
\text { - } \quad \text { Gouity }<10 \% \text { ) } \\
\text { - } \quad \text { Family firm, cautious management } \\
\text { - } \quad \text { World leader on its market } \\
\text { - } \quad \text { Unique know-how } \\
\text { - } \quad \text { Strong development of the ultra-premium } \\
\text { wine market (growth estimate: } 17 \% \text { from } \\
2004 \text { to } 2009 \text { ) }\end{array}$ & $\begin{array}{l}\text { - } \quad \text { Considerable working capital } \\
\text { - } \quad \text { All in all, the wine market has low growth } \\
\text { opportunities } \\
\text { - Declining US dollar } \\
\text { - Alcohol consumption laws increasingly } \\
\text { restrictive } \\
\text { - Climatic risks }\end{array}$ \\
\hline
\end{tabular}

\section{Economic Conditions}

- No large acquisition seems to be in the pipeline.

- A falling US dollar is a risk for the Company (35\% of sales are made in the US).

- The potential for additional margin improvement (EBITDA/Sales) looks limited in the coming years (2007-2009).

- The Net Profit for year 2007 could suffer from persistent difficulties in Australia (Company expects another $8-10 \%$ drop in sales in this country).

- The Net Profit for year 2007 could suffer from unfavorable weather conditions in France. 
Balance Sheet Statement (in $€$ million)

\begin{tabular}{lllll}
\hline Balance Sheet-Assets & $\mathbf{2 0 0 3}$ & $\mathbf{2 0 0 4}$ & $\mathbf{2 0 0 5}$ & $\mathbf{2 0 0 6}$ \\
\hline Total Currents Assets & 104.6 & 105.9 & 108.8 & 128.4 \\
$\sim$ Cash and Equivalents & 11.4 & 9.5 & 10.0 & 16.1 \\
$\sim$ Receivables & 12.5 & 17.8 & 17.6 & 24.0 \\
Inventories & 76.2 & 78.5 & 81.2 & 88.4 \\
Fixed Assets & 14.3 & 15.0 & 16.2 & 26.8 \\
\hline Total Assets & 118.9 & 120.8 & 125.0 & 155.3 \\
\hline \multicolumn{7}{c}{} & & & \\
\hline Balance Sheet-Liabilities & $\mathbf{2 0 0 3}$ & $\mathbf{2 0 0 4}$ & $\mathbf{2 0 0 5}$ & $\mathbf{2 0 0 6}$ \\
\hline Debt and provisions & 44.2 & 37.7 & 31.0 & 45.5 \\
$\sim$ Current Liabilities $(1)$ & 43.9 & 33.9 & 28.3 & 34.6 \\
$\sim$ Long Term Debt & - & 3.2 & 2.0 & 9.3 \\
$\sim$ Deferred Liabilities & 0.2 & 0.3 & 0.4 & 0.6 \\
Minority Interests & 0.6 & 0.6 & 0.7 & 1.1 \\
Shareholders' Equity $(2)$ & 74.2 & 82.5 & 93.2 & 108.7 \\
\hline Total Liabilities & 118.9 & 120.8 & 125.0 & 155.3 \\
\hline
\end{tabular}

(1) Current Liabilities include: Supplier Credit, Operating Debts and Short-Term Financial Debts.

(2) December 31 st 2007: 5,420,000 Common Shares.

Income Statement (in € million)

\begin{tabular}{llllllllll}
\hline & \multicolumn{4}{c}{ Actual } & & \multicolumn{3}{c}{ Estimate } \\
\cline { 2 - 3 } \cline { 8 - 9 } & $\mathbf{2 0 0 3}$ & $\mathbf{2 0 0 4}$ & $\mathbf{2 0 0 5}$ & $\mathbf{2 0 0 6}$ & & $\mathbf{2 0 0 7} \mathbf{e}$ & $\mathbf{2 0 0 8}$ e & $\mathbf{2 0 0 9} \mathbf{e}$ \\
\hline Sales & 70 & 72 & 77 & 91 & & 96 & 100 & 103 \\
EBITDA & 19 & 19 & 21 & 25 & & 27 & 28 & 29 \\
/ Sales & $27.1 \%$ & $26.4 \%$ & $27.3 \%$ & $27.5 \%$ & & $28.1 \%$ & $28.0 \%$ & $28.2 \%$ \\
EBIT & 17 & 18 & 19 & 24 & & 25 & 26 & 27 \\
/ Sales & $24.3 \%$ & $25.0 \%$ & $24.7 \%$ & $26.4 \%$ & & $26.0 \%$ & $26.0 \%$ & $26.2 \%$ \\
Net Profit & 10 & 11 & 12 & 15 & & 16 & 17 & 18 \\
/ Sales & $14.3 \%$ & $15.3 \%$ & $15.6 \%$ & $16.5 \%$ & & $16.7 \%$ & $17.0 \%$ & $17.5 \%$ \\
\hline Return on Equity (3) & $13.5 \%$ & $13.3 \%$ & $12.9 \%$ & $13.8 \%$ & & $13.4 \%$ & $12.9 \%$ & $12.4 \%$ \\
\hline
\end{tabular}

(3) The Return On Equity (RoE) is the Net Profit to Shareholders' Equity ratio.

\section{Ratios (EUR)}

\begin{tabular}{lccccccccc}
\hline & \multicolumn{4}{c}{ Actual } & & \multicolumn{3}{c}{ Estimate } \\
\cline { 2 - 4 } \cline { 9 - 11 } & $\mathbf{2 0 0 3}$ & $\mathbf{2 0 0 4}$ & $\mathbf{2 0 0 5}$ & $\mathbf{2 0 0 6}$ & & $\mathbf{2 0 0 7}$ e & $\mathbf{2 0 0 8}$ e & 2009 e \\
\hline Earnings Per Share (EPS) & 2.11 & 2.19 & 2.36 & 2.80 & & 3.00 & 3.18 & 3.32 \\
Cash-flow Per Share (CPS) & 2.15 & 2.54 & 2.54 & 2.99 & & 3.36 & 3.58 & 3.76 \\
Dividend Per Share (DPS) & 0.31 & 0.35 & 0.38 & 0.50 & & 0.55 & 0.61 & 0.67 \\
\hline
\end{tabular}

\section{Sector Comparison}

The following table presents the Return on Equity of firms close to Tonnellerie Poillanges SA. These Eurozone firms belong to the "Food: Distillers and Brewers" Dow Jones sector. Their market capitalizations are close to Tonnellerie Poillanges SA capitalization (from half to two times).

\begin{tabular}{lcccc}
\hline & \multicolumn{4}{c}{ Actual } \\
\cline { 2 - 5 } & $\mathbf{2 0 0 3}$ & $\mathbf{2 0 0 4}$ & $\mathbf{2 0 0 5}$ & $\mathbf{2 0 0 6}$ \\
\hline Return on Equity & $9.5 \%$ & $10.6 \%$ & $6.2 \%$ & $12.0 \%$ \\
\hline
\end{tabular}

